\title{
ITALIAN AUCTION MARKET: FEATURES OF DISCOUNTED FORCED SALE PRICE
}

\author{
Paola Amoruso \\ Lum Jean Monnet University \\ e-mail:paola.amoruso@alice.it \\ Massimo Mariani \\ Lum Jean Monnet University \\ e-mail:mariani@lum.it \\ Maurizio d'Amato \\ Politecnico di Bari \\ e-mail:madamato@fastwebnet.it

\section{Raffaele Didonato \\ EY Advisory}

\begin{abstract}
The purpose of the paper is to investigate the main causes of discount between list price and forced sale value in the Italian real estate auction segment, in favor of more comprehensive determination of the value of mortgage underlying guarantees; this would allow for an improvement of further valorization processes of assets intended to obtain a higher selling price.

Starting from the results of existing literature, an ordinary least squares regression analysis was conducted in order to point out the main determinants of the discount between list price and forced sale value. It has been verified, when sampling 225 cases of forced residential property sales in the South of Italy, that the time constraint of the Italian regulatory framework is more relevant with reference to discount rather than the physical characteristics of assets.

The influence of the duration of procedures is proof that even if recent government initiatives have led to positive results in terms of reducing the length of procedures, this is not yet satisfactory compared to other European contexts. This provides evidence of the need for further interventions aimed at improving the efficiency of the procedural system, also encouraging recourse to other options that lead to ease judicial burden.
\end{abstract}

Key words: real estate, NPLs, forced sale value, market value, estate auction.

JEL Classification: $L 85, R 23, R 28, R 30$.

Citation: Amoruso, P., Mariani, M., d'Amato, M., Didonato, R. (2020). Italian auction market: features of discounted forced sale price. Real Estate Management and Valuation, 28(3), 12-23.

DOI: https://doi.org/10.1515/remav-2020-0020

\section{Introduction}

The performance of the real estate market plays a significant role in the national economy since the Italian property industry is a substantial part of total investments by both private and business stakeholders. To better understand the dynamics of this scenario, it should be kept in mind that much of the real estate segment is based on the credit market. The biggest current obstacle is the impossibility to sell foreclosed real estate properties, comprising houses, offices, commercial assets 
and industrial buildings, at the assessed value: considering that, on average, every auction in Italy goes deserted many times and that a reduction of list price occurs on each occasion; as of 2018, real estate assets at auction were $245,100 €$, up $4.6 \%$ from the previous year. At the beginning of 2019, properties being sold had a bidding of approximately $€ 51.38$ billion, with a real market value of almost $€ 128.5$ billion. Nevertheless, auctions are perceived by creditors, for $95 \%$ banks, as the main instrument in property loan recovery (Governale, 2018).

The Italian real estate auction sector has changed over time. In the past, it was mainly driven by professional operators, who bought properties in order to redevelop and place them back on the traditional market. It implied a low valuation of properties in favor of speculative behavior and, consequently, auctions that often failed. Thanks to more effective and clear advertising and the transparency of information, this market has recently attracted a new category of potential buyers interested in properties for themselves, allured by prices that are, on average, 31\% lower than those on the traditional market. Despite some positive changes, the perception of this market remains a prerogative of professional operators, also reflecting concerns regarding bureaucracy. This circumstance has led the real estate auction market being constantly characterized by a downtrend. This notice is supported by Donner (2017), who investigated how professional buyers take advantage of discounted prices, buying more than one foreclosed property. The Italian real estate auction market of primary cities, such as Milan and Bologna, is characterized by an average discount of $44 \%$ on sale price compared to the traditional market, more than $10 \%$ higher than the national average. Secondary cities, such as Bari and Florence, stand at a level between $31 \%$ and $36 \%{ }^{1}$.

One of the major problems is represented by the extension of the time of real estate auctions in the domestic context; as of 2018, a property remains at auction, on average, 1.533 days before finding a buyer, with an even longer time span in regions such as Sicily, which has an average of more than 8 years. The reason is trivial: the number of investors in this segment is limited, thus real estate auctions continue to remain a prerogative of few operators interested in buying at low prices; this creates the vicious circle of deserted auctions, until the price of the property reaches very low levels. A lack of efficiency in the Italian real estate foreclosure process has been due to the separation of legal procedure sales from the competitive real estate market; this generates limited participation at auctions of potential buyers, with auctions monopolized by small groups operating with speculative intents (Fontana \& Vigorito, 2007). The relevance of professional operators in the auction segment is a recurring aspect, even in foreign contexts (Donner, 2017).

In the light of the above, between 2005 and 2018, the Italian government modified sales methodology several times in order to reduce the time of procedures and encourage the increase of forced sale prices, reducing both discounts and the number of insolvencies (Marcucci, et al., 2015). A point of recent attention is greater visibility guaranteed, for example, by an online platform for public foreclosure auctions.

Initiatives of past governments intended to facilitate a solution, for instance with a fiscal incentive that was granted to buyers taking part in auctioning and with the possibility of investors proposing a price already $25 \%$ lower than the list price. Furthermore, the legislation allows bidders to arrange loans with financial institutions and set the auctioned properties as collateral, in order to promote transactions. In this respect, data on foreclosures and failure published by Moody's in November 2018, revealed an increase in Italian court efficiency on NPLs (non-performing loans), especially in the South of Italy; in fact, the published results have shown that, in 2017, completed procedures outnumbered new ones for the first time. The national average of the ratio of new procedures to completed ones stands at $89 \%$ (as compared to $124 \%$ in 2014 ), with, $84 \%$ in the South of Italy. The north and the central areas present higher percentages because of the major inflows of NPLs. Even despite this positive result of government reforms of 2014-2017, the overall duration of procedures in Italy is far behind the European average.

Many banks and operators of the NPL sector are developing alternative solutions to increase the participation of investors at auctions in order to create competition on individual properties, avoiding sales with significant discounts. Among the developed solutions, some banks have created real estate companies named "Reoco" (real estate owned companies), owned by the banks themselves. One of the major initiatives in this field has been promoted by Intesa Sanpaolo: the Reoco of Intesa hired 30 people specialized in the real estate market able to analyze each property deriving from NPL of the

\footnotetext{
${ }^{1} 2018$ Report- Press office Immobiliare.it (Italian real estate portal)
} 
group, allowing investors to understand its real market value. Thus, Intesa Sanpaolo Reoco can participate at auction, with the mandate to buy the asset if its base price falls below a certain threshold. The primary objective is to generate the virtuous effect of repopulating auctions and to bring up the prices; otherwise, the Reoco itself can proceed to the purchase in order to enhance the value of the acquired property, thereafter implementing processes aimed at increasing the value of assets.

In this sense, an additional resolution strategy is represented by real estate securitization, consisting in a typical form of financing used to purchase NPLportfolios. Securitization involves pooling individual, usually illiquid, assets underlying NPL and using the pool as collateral for the issuance of an entirely new set of financial securities named ABS (asset backed securities); ABS investors are promised a proportionate share of the cash flows produced by the pool of assets (Goddard \& Marcum, 2012).

A major limit in the development of real estate securitization as an alternative solution is the difference between the purchase price of assets and their estimated market value.

In this view, in the Italian real estate market, the efficient liquidation of underlying real estate assets is favored among the innovations introduced by the recent conversion law of the Decree n. 50/2017 on NPL securitization. In this regard, the real novelty is the introduction of the ReoCo in real estate securitization operations, with the extension of the benefit of segregation to all the proceeds achieved by the ReoCo, intended to meet the rights incorporated in the issued ABS and the payment of transaction costs, assimilating real estate management flows to the payments of ceded debtors.

In the light of the fact that the great majority of deteriorated loans has real estate property as guarantee, the systematization of ReoCo is relevant. Moreover, the Reoco can develop all those valorization processes of assets, denied to the SPV, such as activities connected with renovation, alignment/urban conversion, development and renegotiation of leases.

The aim is to reduce the considerable gap between the purchase price in real estate securitization operations and the estimated market value of underlying assets, which has, so far, not allowed the effective development of securitization as an alternative solution in real estate NPL management.

Starting from the current state of the Italian real estate auction segment, the present work aims to explain the gap between the list price and forced sale value, considering that list price is determined as the estimated market value by independent experts with a discount of $15 \%$, consistently with the Italian auction system. A set of different variables will be analyzed, such as physical features of properties and other characteristics associated with the legal procedure. It is expected that the time constraint of the Italian regulatory framework exerts a greater influence on discount rather than physical variables; therefore, it is considered that the effects of time-related variables will probably be significant; moreover, the developed analysis allows the possible influence of other selected physical characteristics to be verified.

\section{Literature Review}

\subsection{Forced sale value in international literature}

In existing literature, several contributions have investigated the relationship between the auction market and the segment of private negotiation in terms of the realization of the final transaction price. In this regard, the focal point is represented by the difference between Market Value and Forced Value. Market value is intended as "the estimated amount for which an asset or liability should exchange on the valuation date between a willing buyer and a willing seller in an arm's length transaction, after proper marketing and where the parties had each acted knowledgeably, prudently and without compulsion" (International Valuation Standards, 2017). On the other hand, the term "forced sale" reflects circumstances where a seller is under compulsion to sell and, consequently, a proper marketing period is not possible. The price that could be obtained will depend upon the specific nature of the constraining conditions; this issue will imply the possibility of the seller failing to sell within the period available. Although a forced sale is a description of the situation under which the exchange takes place and not a distinct basis of value, the final price in a forced sale will reflect its particular circumstances rather than those of the hypothetical willing seller in the Market Value definition (International Valuation Standards 2016).

In the Italian auction segment characterized by discounted sale price, the main difference compared to the traditional market is the constant downtrend, which has always been a salient 
feature; in the real estate auction market, sale prices of foreclosed properties are higher than list prices in only exceptional cases. However, sale mechanisms might vary considerably within states depending on local legal and customary practices (Pennington-Cross, 2006). Therefore, research on forced sales will exhibit consistent differences because of local institutional conditions, as demonstrated by Donner (2017), who found evidence of the importance of the regulatory framework with respect to the achieved sales price. It should be clarified that not all foreign auction markets have been characterized by discount. To understand the experience already gained in the auction market, significant characteristics compared to discount between forced sale value and list price have been examined, both in international and national literature; the gap between list price, intended as the amount required for a property, and final forced sale price can generally be considered as a proxy of the ability to gain the highest expected value from an auction.

Susilawati and Lin (2006) have presented an interesting comparison of the auctions market with reference to various nationalities, highlighting different results in terms of premium or discount, depending on the analyzed country. The authors found that only the Australian and Irish auction markets of the investigated sample are characterized by a premium on the final sale price, in contrast to their counterparts such as the United States, Taiwan and Singapore, which presented a discount. The reason is the difference in the auction system of a national context; in this regard, PenningtonCross (2006) did well to explain that foreclosures have a greater negative influence on prices in American states that require a judicial foreclosure process compared to those that do not.

Investigating the Australian scenario, Lusht (1996) presented a regressive analysis on prices considering the following independent variables: the size of the property, age, number of services, location, conservative status, construction characteristics, date of sale and sales market. In particular, he partly justified premiums on the Australian auctions market affirming that sale procedures in this segment covered half of the real estate sales at the national level. Lusht increased the number of variables inserted in the hedonic model, compared to the previous studies. Similarly, Dotzour et al. (1998) set characteristics such as the size, both of the pertinence and of the property, age, construction quality, finishing conditions, structural type, location, sales market and interest rates of mortgages at the considered time as independent variables. The authors underlined, similarity to Lusht (1996), the profound difference between the Australian market and the American one in order to justify the premium in Australian auction prices. In fact, as pointed out by the authors, the difference is to be found in the dependence of the American auction real estate market on mortgage foreclosure, tax foreclosure, divorce and estate settlement. This notion is supported by the fact that auctioning is not comparable to a sale by a real estate broker and, consequently, sales prices often occur at a perceived discount to fair market value.

In this regard, in American literature, several scholars have demonstrated how real estate sales at auction are characterized by discount compared to free negotiation of the market. Mayer (2003), Marcus (2001) and Quan (2002), consistently with Dotzour et al. (1998), highlighted the difference between the use of the American auction market and the Australian one, considering the substantial difference between the free competitive market and foreclosed sales in the national system. Allen and Swisher (2000) analyzed a sample of properties in Fort Lauderdale finding that they are sold at a discount, and considered whether the order of sale of the auctioned properties affects the observed prices. Ong (2006) pointed out how the time to re-auction has a negative effect on the auction price, revealing that sellers use subsequent auctions as a search process for new bidders. The author also noted an influence of the asset type, with negative performance of atypical properties. However, early studies referred to a time variable identified seller incentive for a quick sale as the cause for a foreclosure discount (Forgey, et al., 1994; Hardin \& Wolverton, 1996; Shilling, et al., 1990).

Campbell et al. (2011) developed a study on a sample of about 1.8 million foreclosed properties sold at auction in Massachusetts in the last 20 years, revealing an average discount of $28 \%$ compared to the value of buildings in the same district sold on the traditional market; they found a relevant influence of the maintenance status. This research also highlighted the negative influence that auctions had on trades of neighboring properties, on average lowering the price about $1 \%$ within 0.05 miles. Wong (2017) showed how auction characteristics, such as proximity to the city center, number of previous auction attempts and number of online viewers, considered as new variables analyzed in literature, are positively related to sale price and sale probability. Clauretie and Daneshvary (2009) found that the physical conditions of the property and the relationship between marketing time and price influence a discount on the sale value of foreclosed properties. Several additional models in 
existing literature have included the standard (hedonic) physical characteristics of residential properties as in the case of Shilling et al. (1990), Forgey et al. (1994), Hardin and Wolverton (1996) and of Carroll et al. (1997). However, more recent studies showed that physical characteristics of the asset lose relevance compared to the local regulatory framework (Donner, 2016); it has been demonstrated that the structure of auction system exerts a major influence on price discount. According to Donner (2017), the foreclosure status is one of the main causes of discount, rather than the property characteristics. The number of recipients is an additional factor often investigated in existing research; Hungria-Gunnelin (2013) considered the number of bidders, demonstrating that the amount of possible investors in a real estate auction exercises a positive influence on the final auctioned price. On the other hand, Knight et al. (1994) showed that a lower list prices could increase the number of bidders, simultaneously reducing the bid offered by each participant.

\subsection{Evidence from Italian experience}

The Italian auction market is similar to the American one in terms of the discount on final sale price; with particular reference to the domestic context, a comprehensive survey on the Italian Real Estate distressed market has been provided by Canesi and Marella (2018), focusing on property foreclosures occurring in north-eastern Italy, specifically in the Veneto Region; socio-economic characteristics concerning housing market trends and demographic features were considered in order to relate the performances of a distressed market to the surrounding urban context; the analyzed aspects were physical location, income, variation of normalized number transactions (NTN), population and real estate activity index (IMI). Furthermore, other characteristics, such as profitability in terms of occupancy, physical features (such as type, state of maintenance, gross building area and quality) and auction market features (days on market, number of auctions, discount, premium and date of value) were included. Moreover, in their (2016) work, the authors also investigated the discount between list price and forced sale value, analyzing a sample of forced property sales in the North of Italy and trying to empirically quantify the existing discount. An interesting comparison between the value regarding forced sale and average market value has been presented by RENIGIER-BIŁOZOR et al. (2018); they have introduced the use of automated valuation methods (AVM) in the determination of property value for forced sales, basing the analysis on two property markets: the city of Bari (Italy) and the city of Olsztyn (Poland). The results showed that forced sale value is about $45 \%$ lower in the case of Bari, a city of the South of Italy also included in the sample of the current study.

In the light of past experience, the present work aims to provide a further contribution, investigating the Italian real estate auction market and analyzing the discount between list price and forced sale value as a function of several variables, i.e.: a set of physical features, characteristics related to the local housing market trend and a representative variable of procedure length. It is expected that a local regulatory framework exerts a negative impact on price, especially due to the time constraint, foreseeing that this will present a greater influence than the physical conditions of the property.

\section{Study methodology}

The verified basic condition that reflects the major limit of the real estate auction process is the difference between the list price $(P l)$ and forced sale value $(P s)$; the specification process itself can end up destroying some of the value that should be gained in a balanced system. In this regard Knightet et al. (1994) found a close relation between the list price and selling price of a property, with an emphasis on the crucial importance of market value assessed by valuers. However, the problem is to be found in the difference between them: the greater this gap, the smaller the possibility of recovering the entire amount of the loan. Moreover, a higher distance between list price and forced sale value typically corresponds to longer time procedures, since list price will be reduced at every deserted auction. Different reliable explanations have been found over time; generally, the magnitude of the deviation would be sensitive to loan characteristics, legal restrictions, housing market conditions and marketing time (Pennington-Cross, 2006). The specifics of a real estate property (such as its dimensions, intended use, state of maintenance, floor) have been also investigated in existing literature and different contexts in order to establish which of these most influence the deviation; conflicting results have emerged, suggesting that the discount between the list price and forced sale value is due to the foreclosure status and the local regulatory framework. Following the existing literature, the present work analyzes the gap between forced sale value and list price in terms of 
percentage discount as a dependent variable, also considering the great influence exerted by procedure length, thus expecting a relevant significance of the time-related variable, consistent with results obtained by Donner (2016), who pointed out the impact of the time constraint on sale price. In the light of existing literature, selected time-related variables will be the time on auction and a variable named IMI, representative of annually estimated market dynamics as a function of the exact geographical location (this index is normally available only annually); commercial surface, private and shared outbuildings, the presence of an elevator and the state of maintenance will be assumed as the physical features.

These characteristics will be investigated with respect to two different concepts of value: the list price $(P l)$, corresponding to the estimated market value assessed by the valuer at the beginning of the auction process with a 15\% discount (as provided in the Italian auction system), and the sale price $(P s)$, intended as the final clearing price of auctioned property. The dependent variable, represented by the percentage discount between the list price and forced sale value, was determined for each observation as follows:

$$
\text { Percentage Discount }=\frac{P l-P s}{P l}=1-\frac{P S}{P l}
$$

Data on forced sales was collected from Astegiudiziarie, a telematic portal which allows to look at promoted and completed sales in Italian courts, with a brief historical interlude, since information on awarded auctions are available just for a brief period after the award. The analysis has been carried out on a sample of 225 auctions over the period 2014-2018; the analyzed residential properties are located in the province of Bari, Taranto and Bat, classed as secondary cities in the South of Italy. Due to the limited variability of the sample, especially regarding the size of the residential properties included, all the analyses on the dataset have been conducted considering unweighted values for each property. Further development of the research could include an adjustment based on the size of the property or the other variables observed. The focus on a contiguous area would allow biased results caused by the lack of spatial control variables such as spatial price interdependence to be avoided (Clauretiev\& Daneshvary 2009). According to a recent study, the average discount characterizing the real estate auction segment in Bari in the last year is about 36\% lower than the traditional market, which is $6 \%$ lower than the national average. It is expected that the cause of this issue is due to the speculative nature of the auction system, as well as due to the time on auction, seeing as how the low efficiency of the process is caused primarily by the length of the procedure. In this regard, the negative influence of foreclosure status on price has been investigated by Donner (2017), leading to the conclusion that discount is not a proxy effect driven by property characteristics.

For each single transaction, real estate evaluation reports produced by independent valuers were analyzed, investigating a set of specific elements such as location, urban context, residential type, size, pictures, typology and date of construction, state of maintenance, estimated market value and estimation date, bidding and final auction price, methodology applied by valuers, urban and cadastral compliance, the date of sale and the number of bidding proceedings (Canesi, et al., 2016). As is well known, market segments associated with several intended uses (such as stores, residential, industrial, office, etc.) are characterized by different liquidity levels (Forte \& De Rossi, 1974); therefore, in order to avoid disturbances in the reliability of results, a sample with an individual intended use has been selected, referring to the residential segment.

The first descriptive analysis took into consideration a set of features in order to provide a comprehensive overview of the reference sample; thereafter, OLS regression on investigated variables was carried out in order to point out the main determinants of discount between forced sale value and list price. Property location (L) depends on its distance from the provincial capital, considering each observation for the relative provincial macro-area and identifying it as central, semi-central or suburban. Moreover, each macro-area is associated with a specific index representative of market dynamics, named IMI and annually determined as the ratio of NTN (normalized number transactions) to the available stock ${ }^{2}$. The choice of the MI variable allows the trend of bought and sold properties to be realistically taken into account with respect to the available stock in selected provincial macro-areas

\footnotetext{
2 NTN and IMI indices, for each Italian region, are annually published by Agenzia del Territorio; the report named "Statistiche regionali - Regione Puglia - 2018", includes indications of real estate market dynamics depending on geographical location in the Puglia Region.
} 
at the time of the sale; it specifies the percentage difference of sold properties compared to those available (Del Giudice \& D'amato, 2008). Consequently, the introduction of this variable allows for the trend of the real estate free competitive residential market (Pennington-Cross, 2006) and influence of geographical location to be considered in accordance with the hypothesis of the existence of different housing submarkets at a given time, defined as a function of geographic areas (Goodman \& Thibodeau, 1998). In order to verify the influence of the regulatory auction framework and foreclosure status rather than the property's physical conditions, existing models, which included physical characteristics of residential properties, have been considered, such as those presented by Shilling et al. (1990), Forgey et al. (1994), Hardin and Wolverton (1996), Carroll et al. (1997), Clauretie and Daneshvary (2009) and Dotzour (1998). These authors selected characteristics such as size (including pertinence), age, quality, finishes conditions, structural type and location as independent variables.

The present analysis included the following variables as a proxy of physical conditions: property size in terms of commercial surface ( $\mathrm{S}$ in $\mathrm{m} 2)$; state of maintenance $(\mathrm{M})$, a qualitative variable expressed by the ranking of increasing score from 0 to 4 (inadequate, poor, adequate, good, excellent); private and shared outbuildings $(\mathrm{O})$ and the presence of an elevator $(\mathrm{E})$, measured as dummy variables. Finally, the time on auction (TOA in years) was included, determined as the temporal difference between the first day of bidding and auction clearing date, consistent with Donner (2016), who investigated the impact of the time constraint on the achieved prices.

\subsection{Descriptive statistics}

A descriptive - statistical analysis of selected samples is provided below; as for the physical features of selected properties, the sample includes different construction typologies, such as individual buildings, apartments, semi-dependent properties and entire residential blocks. The average size of the auctioned properties is $112 \mathrm{~m} 2$, with evident positive asymmetry. More than half of the sample presents an adequate or better state of maintenance, with the remaining characterized by degraded conditions. About $97 \%$ of selected properties have outbuildings, $51.3 \%$ of which are either shared and private. Around $60 \%$ of the samples have no elevator, as in the case of individual buildings or, sometimes, old constructions.

Table 1

Descriptive statistics 2014-2018

\begin{tabular}{|c|c|c|c|c|c|c|c|c|}
\hline Description & Obs. & Mean & Std. Dev. & Median & Skewness & Kurtosis & Min. & Max. \\
\hline $\begin{array}{c}\text { Type of } \\
\text { property }\end{array}$ & & & & & & & & \\
\hline Residential & $\begin{array}{c}225 \\
(100 \%)\end{array}$ & & & & & & & \\
\hline Size & 225 & 133.393 & 119.173 & 112.175 & 3.745 & 17.161 & 12.000 & 916.000 \\
\hline $\begin{array}{c}\text { State of } \\
\text { maintenance }\end{array}$ & 225 & 2.013 & 0.966 & 2.000 & -0.027 & -0.295 & 0 & 4 \\
\hline Inadequate & $\begin{array}{c}13 \\
(6.2 \%)\end{array}$ & & & & & & & \\
\hline Poor & $\begin{array}{c}51 \\
(22.6 \%) \\
\end{array}$ & & & & & & & \\
\hline Adequate & $\begin{array}{c}94 \\
(41.7 \%) \\
\end{array}$ & & & & & & & \\
\hline Good & $\begin{array}{c}54 \\
(23.9 \%) \\
\end{array}$ & & & & & & & \\
\hline Excellent & $\begin{array}{c}13 \\
(5.7 \%)\end{array}$ & & & & & & & \\
\hline Elevator & $\begin{array}{c}80 \\
(35.5 \%) \\
\end{array}$ & & & & & & & \\
\hline No elevator & $\begin{array}{c}145 \\
(64.4 \%) \\
\end{array}$ & & & & & & & \\
\hline Outbuildings & 218 & & & & & & & \\
\hline
\end{tabular}




\begin{tabular}{|c|c|c|c|c|c|c|c|c|}
\hline & $(96.9 \%)$ & & & & & & & \\
\hline Private & $\begin{array}{c}61 \\
(27.1 \%)\end{array}$ & & & & & & & \\
\hline Shared & $\begin{array}{c}41 \\
(18.2 \%)\end{array}$ & & & & & & & \\
\hline $\begin{array}{l}\text { Private and } \\
\text { shared }\end{array}$ & $\begin{array}{c}116 \\
(51.5 \%)\end{array}$ & & & & & & & \\
\hline $\begin{array}{c}\text { No } \\
\text { outbuildings }\end{array}$ & $\begin{array}{c}7 \\
(3.1 \%)\end{array}$ & & & & & & & \\
\hline Location & 225 & & & & & & & \\
\hline Central & $\begin{array}{c}56 \\
(24.8 \%)\end{array}$ & & & & & & & \\
\hline Semi-central & $\begin{array}{c}95 \\
(42.2 \%) \\
\end{array}$ & & & & & & & \\
\hline Suburban & $\begin{array}{c}74 \\
(32.8 \%) \\
\end{array}$ & & & & & & & \\
\hline TOA (years) & 225 & 2.291 & 2.160 & 1.411 & 1.164 & 0.346 & 0.000 & 8.844 \\
\hline IMI & 225 & 1.63 & 0.24 & 1.57 & -0.32 & -0.19 & 1.03 & 1.96 \\
\hline $\mathrm{Pl}$ & 225 & 154871.02 & 130842.60 & 128227.00 & 2.93 & 13.50 & 1000.00 & $\begin{array}{c}1 \\
021295.00\end{array}$ \\
\hline Ps & 225 & 79382.67 & 70537.72 & 61000.00 & 2.44 & 9.44 & 750.00 & 500000.00 \\
\hline $\mathrm{D}$ & 225 & 0.459 & 0.232 & 0.448 & -0.769 & 1.40 & -0.435 & 0.901 \\
\hline
\end{tabular}

Source: own study.

As for the location, depending on the specific provincial macro-area, almost half the sample is in semi-central areas $(42.5 \%)$, followed by properties in suburban contexts $(32.7 \%)$ and, finally, those with central locations $(24.8 \%)$.

The time on auction varies from a minimum of 0 , in cases of sale at first bidding, to a maximum of 8 , indicative of extreme procedure lengths, which is an alarming figure. There is a parallel between findings for the North of Italy is noted, with an average of approximately 2.2 years (Canesi, et al. 2016), and the obtained value for the South, equal to 2.3 years, with a maximum value in both cases in the range of 7 to 8 years. This reveals the extent of the problem, due to the national regulatory framework. Such a long timetable generates a sharp downturn of sale value, in favor of the speculative behavior of investors who bought the properties in order to resell them as an incentive to capture gains caused by a price discount (Donner, 2017).

The IMI variable, indicative of market dynamics, has an average value of $1.6 \%$, revealing a slowly recovering trend, with a relatively stagnating real estate market in areas where selected properties were located.

The mean discount of the whole residential sample is equal to $45.9 \%$ of the list price and this figure is consistent with the results achieved by Renigier-Biłozor et al. (2018).

For a deeper evaluation of the deviation between the list price and the forced sale value, Mean absolute percentage error (MAPE) and the Coefficient of Dispersion (COD) were computed on the sample, resulting in a MAPE of $130.2 \%$ and a COD of $46.4 \%$. Expectedly, the sample shows significant differences between forced sale values and list prices, and, in fact, the forced sale value is lower than the list price for $96.0 \%$ of the samples due to the typicality of the auction process.

The correlation between selected variables is exposed below. Th highest correlation values have been predictably recognized between the list price and forced sale value, since the latter arises from the reduction of a certain flat rate at every failed auction.

Moreover, a significant correlation between list price and size has been observed in terms of commercial surface; this is obvious since real estate assessment is typically determined as a function of the property's surface. Similarly, for the above-mentioned reasons, a certain correlation has been found between size and forced sale value. All other variables present no significant correlation between them, allowing multicollinearity to be avoided. 


\subsection{Regression model}

Most of the existing literature on foreclosures has used a single-equation ordinary least squares (OLS) test in order to investigate the main determinants in the auction segment (LUSHT 1996; DOTZOUR et al. 1998; WONG et. al. 2015; ANDERSEN, NIELSEN 2013). Thus, the developed analysis will be based on OLS regression methodology, assuming the percentage discount between list price and sale price as dependent variable, determined as already given (1). The performed model can be formally described as follows:

Table 2

Correlation matrix

\begin{tabular}{c|cccccc}
\hline & Ps & Pl & Size & State of maintenance & TOA & IMI \\
\hline Size & 0.43 & 0.71 & 1.00 & & & \\
\hline State of maintenance & 0.28 & 0.27 & 0.12 & 1.00 & & \\
\hline TOA & -0.09 & 0.14 & 0.15 & -0.06 & 1.00 & \\
\hline IMI & 0.31 & 0.15 & -0.09 & 0.05 & 0.00 & 1.00 \\
\hline
\end{tabular}

Source: own study.

Percentage Discount $_{i}=1-\frac{\mathrm{Pl}}{\mathrm{Ps}}=\beta_{1}$ Size $_{i}+\beta_{2}$ State of Maintenance $_{i}+\beta_{3}$ Outbuildings $_{i}+\beta_{4} \mathrm{TOA}_{i}+\beta_{5} \mathrm{IMI}_{i}+\varepsilon(2)$

Table 3

Estimation results of OLS model

\begin{tabular}{|c|c|c|c|c|}
\hline Independent variables & Estimate & Std. Error & p-value & Signif. codes \\
\hline Size & 0.0004 & 0.0001 & 0.0039 & $* *$ \\
\hline State of maintenance & 0.0203 & 0.0147 & 0.1692 & \\
\hline Outbuildings & 0.0391 & 0.0306 & 0.0147 & * \\
\hline TOA & 0.0559 & 0.0066 & 3.05E-15 & $* * *$ \\
\hline IMI & 0.0882 & 0.0277 & 0.00167 & ** \\
\hline \multicolumn{5}{|c|}{ Signif. codes : $00^{\prime * * * \prime} 0.001^{\star * * \prime} 0.01^{\star * \prime} 0.05^{\prime} !^{\prime} 0.1^{\prime \prime} 1$} \\
\hline Multiple R-squared & 0.8352 & & & \\
\hline Adjusted R-squared & 0.8314 & & & \\
\hline Residual st. error & $\begin{array}{r}0.211 \text { on } 220 \\
\text { degrees of } \\
\text { freedom }\end{array}$ & & & \\
\hline f-statistic & $\begin{array}{r}222.9 \text { on } 5 \text { and } 220 \\
\text { DF }\end{array}$ & & & \\
\hline p-value: & $<2.2 \mathrm{e}-16$ & & & \\
\hline
\end{tabular}

The results for model (2) are shown in Table 3; as the p-value of the model is much lower than 0.01 , the null hypothesis that $\beta=0$ was rejected with a $99 \%$ confidence interval. Hence, there is a significant relationship between the variables used in the linear regression model and the dependent variable.

With reference to statistical significance of the variables, it is possible to observe how TOA is the independent variable whose p-value achieves the highest significance level, confirming the major impact of the aforementioned variable on Discount.

Thus, all the other variables result in higher p-values, consistently to the time-related starting hypothesis. However, significance levels for IMI and Size are considerably higher, suggesting an impact of such variables on Discount in the auction process.

Ultimately, the model described in (2) explains more than the $83 \%$ of the variability of discount, having a Multiple R-squared value greater than 0.83 and an Adjusted R-squared value of 0.831 . 
Finally, a model limitation could be identified in the possible endogeneity arising between the Discount and the TOA. In fact, similarly to the aforementioned list price, the estimated market value is also assessed by independent experts, while the sale price is based on the bid auction process. Such a process is partly influenced by the starting bid level, which is set to decrease linearly as the time on auction increases. In this sense the implementation of a specific instrumental variable offers a possible future direction. However the present analysis is intended to investigate the combined effect of the factors that influence the degree of overpricing and underpricing in the forced sale value, and hence the discount is considered as a dependent value, expressed as a percentage of the list price, as reported in (1).

\section{Empirical results}

The performed analysis allows the main features of Italian forced sales properties in the selected geographical area to be identified; the sample comprises properties with an average size of $112 \mathrm{~m} 2$. Almost half of the sample presents an adequate state of maintenance and most of the selected real estate properties are in semi central municipalities.

Firstly, the quantification of the mean discount was obtained, amounting to approximately $45 \%$ of the list price, proving a more severe condition related to foreclosure in the South of Italy than in the North (Canesi, et al., 2016). Referring to recent analysis, the discount in the Italian context is higher than other investigated countries in existing literature because of the specific operation of the regulatory framework on the auction market (Campbell, et al., 2011).

However, it is appropriate to specify that this result is referred to a sample covering the years 2014-2018; the most recent data for just 2018 showed an average discount of about $36 \%$ less compared to the traditional market. It follows that the most recent government initiatives aimed at facilitating a solution, reducing the time of procedures, encouraging the increase of forced sale prices and lowering both discounts and the number of insolvencies, may have been quite successful, though not enough. The negative impact of the local auction mechanism on price is consistent with Donner's (2016) study.

The influence of time proved significant in the performed model in the case of IMI and TOA, both of which are subject to change over time, in contrast to other selected variables. However, among all physical characteristics, size proved to have a significant effect on discount as well, which could be justified in light of the fact that larger real estate properties are usually harder to place on the market than smaller assets; this notice can exert a consistent influence in the creation of Discount; consequently, this means that smaller distressed properties could probably be sold at a reduced discount, since they may require shorter marketing time. The model limitation due to the possible endogeneity arising between the Discount and the TOA may suggest future directions, with the implementation of a specific instrumental variable. In any case, the present analysis investigates the combined effect of the factors that influence the degree of overpricing and underpricing in the forced sale value.

In terms of the time taken for the sale, the Italian national average (T.S.E.I. Association, 2017) is one of the longest in Europe, despite a certain though insufficient reduction in the recent years. With the French average duration being closer to the domestic context, real estate procedures in Germany take, on average, 9 months, and 8 months in Spain (Italian Banking Association - ABI, 2010).

This gap reveals limits of foreclosure procedures in Italy, with an informative inefficiency which generates a limited participation by potential buyers, with auctions monopolized by small groups operating with speculative intents. In this regard, Donner (2017) found evidence of the interest of professional operators to capture gains, thanks to price discount.

Moreover, the stagnant condition of the real estate segment in the secondary market, especially in semi central ad suburban contexts, certainly exercise a negative influence, as proved by the IMI indicator.

In light of the above, time-related variables have proved to have a significant effect on discount. In fact, TOA directly reflects the time-variable of the auction and IMI is prone to changing over time, even though it is related to other features, such as location and market dynamics.

\section{Discussion and conclusions}

Based on the obtained results, it can be stated that the primary aim should be to reduce the duration of foreclosure procedures which would result in a reduction in the discount; in this sense, government initiatives have led to positive results, though not yet satisfactory compared to other European 
contexts. An analysis on a sample of 225 forced sales between 2014 and 2018 in the Apulian provinces of Bari, Taranto and Bat was carried out; starting from a quantitative determination of the discount between forced sale value and list price, the performed model has allowed the main determinants of the Italian forced sales market to be identified, verifying the influence of the duration of procedures.

The existence of this gap suggests a limited development of this market segment despite auctions still perceived being by creditors as the main instrument in property loan recovery by $95 \%$ of banks. The negative influence of the foreclosure status on price results from the fact that discount is not a proxy effect driven by property characteristics.

In light of the above, the low efficiency of judicial procedures due to the devaluation of assets should lead to the promotion of alternative solutions that can be perceived as equally safe but characterized by lower costs and timeframes.

Consequently, if, on the one hand, interventions aimed at the efficiency of the procedural system are desired, it is also necessary to encourage recourse to other options that also lead to easening the judicial burden; this would create a ripple effect making procedures faster and streamlined.

In this regard, the Italian government, in the wake of European Commission strategies, has already promoted initiatives aimed at encouraging the re-launch of the securitization market, including the real estate segment, in the belief that properly regulated, high quality and transparent securitized products can play an important role in loan collection and, therefore, compete to achieve the goal of returning to sustainable growth.

In this context, with reference to the disposal of receivables with underlying real estate and to the measures introduced by the recent Law of conversion of the D.L. n. 50/2017, the possibility of setting up a ReoCo as part of the securitization program becomes significant. A ReoCo is a company specialized in acquiring, managing and enhancing properties and other assets placed as collateral for NPL which, operatively, is responsible for supporting the clearing price at auction and, if necessary, directly acquiring them before they lose value, with the aim of the efficient management of these real estate properties and liquidity benefit.

The development of such solutions, together with efficiency of a procedural system could allow to implement an auction market segment, reducing speculative behavior in favour of a major equilibrium.

\section{References:}

Agenzia Del Territorio. (2018). Statistiche regionali - Regione Puglia.

Allen, M. T., \& Swisher, J. (2000). An analysis of the price formation process at a HUD auction. Journal of Real Estate Research, 20(3), 279-298.

Andersen, S., \& Nielsen, K. M. (2013). Fire Sales and House Prices: Evidence from Estate Sales due to Sudden Death, Copenhagen Business School Working Paper. https:// doi.org/10.2139/ssrn.2310410

Associazione Bancaria Italiana (ABI). 2010. Audizione sul Mercato Immobiliare. Audizione del Direttore generale dell' ABI, Giovanni Sabatini, ABI Auditions.

Campbell, J. Y., Giglio, S., \& Pathak, P. (2011). Forced sales and house prices. The American Economic Review, 101(5), 2108-2131. https://doi.org/10.1257/aer.101.5.2108

Canesi, R., D'Alpaos, C., \& Marella, G. (2016). Forced Sale Values vs. Market Values in Italy. Journal of Real Estate Literature, 24(2), 377-401.

Canesi, R., \& Marella, G. (2018). Data from RE distressed market: Properties auctions in Italy. Data in Brief, 18, 319-324. https:/ / doi.org/10.1016/j.dib.2018.03.009 PMID:29896519

Carroll, T. M., Clauretie, T. M., \& Neill, H. R. (1997). Effect of Foreclosure Status on Residential Selling Price [Comment]. Journal of Real Estate Research, 13(1), 95-102.

Clauretie, T. M., \& Daneshvary, N. (2009). Estimating the house foreclosure discount corrected for spatial price interdependence and endogeneity of marketing time. Real Estate Economics, 37(1), 4367. https://doi.org/10.1111/j.1540-6229.2009.00234.x

Del Giudice, V., \& D’Amato, M. (2008). Principi metodologici per la costruzione di indici dei prezzi nel mercato immobiliare. Maggioli Editore, Santarcangelo di Romagna.

Donner, H., Song, H. S., \& Wilhelmsson, M. (2016). Forced sales and their impact on real estate prices. Journal of Housing Economics, 34(C), 60-68. https:// doi.org/10.1016/j.jhe.2016.08.002

Donner, H. (2017). Foreclosures, Returns and Buyer Intention. Journal of European Real Estate Research, 39(2), 189-213. 
Dotzour, M. G., Moorhead, E., \& Winkler, D. T. (1998). The impact of auctions on residential sales prices in New Zealand. Journal of Real Estate Research, 16(1), 57-72.

Fontana, R., \& Vigorito, F. (2007). Le procedure esecutive dopo la riforma, La vendita Immobiliare. Giuffrè Editore.

Forgey, F. A., Rutherford, R. C., \& Vanbuskirk, M. L. (1994). Effect of Foreclosure Status on Residential Selling Price. Journal of Real Estate Research, 9(3), 313-318.

Forte C., \& De Rossi B. (1974). Principi di Economia ed Estimo. Etas Libri.

Goddard, G. J., \& Marcum, B. (2012). Securitization of Real Estate Assets. Real Estate Investment, 225252. Springer Texts in Business and Economics. Springer. https://doi.org/10.1007/978-3-64223527-6_11

Goodman, A. C., \& Thibodeau, T. G. (1998). Housing market segmentation. Journal of Housing Economics, 7(2), 121-143. https://doi.org/10.1006/jhec.1998.0229

Governale, S. (2018). Rapporto immobiliare. Milano Finanza.

Hardin, W. G., \& Wolverton, M. L. (1996). The Relationship between Foreclosure Status and Apartment Price. Journal of Real Estate Research, 12(1), 101-109.

Hungria-Gunnelin, R. (2013). Impact of Number of Bidders on Sale Price of Auctioned Condominium Apartments in Stockholm. International Real Estate Review, 16(3), 274-295.

International Valuation Standards Council. (2016). IVS 104: Bases of Value.

International Valuation Standards Council. (2017). IVS 105: Valuation Approaches and Methods.

Knight, J. R., Sirmans, C. F., \& Turnbull, G. K. (1994). Listing Price Signaling and Buyer Behavior in the Housing Market. The Journal of Real Estate Finance and Economics, 9(3), 177-192. https://doi.org/10.1007/BF01099271

Lusht, K. M. (1996). A comparison of price brought by English auctions and private negotiations. Real Estate Economics, 24(4), 517-530. https:// doi.org/10.1111/1540-6229.00702

Marcucci, M., Pischedda, A., \& Profeta, V. (2015). Notes on Financial Stability and Supervision: The Changes of the Italian Insolvency and Foreclosure Regulation Adopted in 2015. Banca D'Italia Eurosistema.

Marcus, A. (2001). Discount in Real Estate Auction Price: Evidence from South Florida. The Appraisal Journal, 69, 28-43.

Mayer, C. J. (2003). Assessing the Performance of Real Estate Auction. Real Estate Economics, 126, 4166.

Ong, S. E. (2006). Price Discovery in Real Estate Auctions: The Story of Unsuccessful Attempts. Journal of Real Estate Research, 28(1), 39-60.

Pennington-Cross, A. (2006). The value of foreclosed property. Journal of Real Estate Research, 28(2), 193-214.

Renigier-Biłozor, M., Walacik, M., Źróbek, S., \& D’Amato, M. (2018). Forced sale discount on property market - How to assess it? Land Use Policy, 78, 104-115. https:// doi.org/10.1016/j.landusepol.2018.06.026

Quan, D. C. (2002). Market mechanism choice and real estate disposition: Search versus Auction. Real Estate Economics, 30(3), 365-384. https:// doi.org/10.1111/1540-6229.00043

Shilling, J. D., Benjamin, J. D., \& Sirmans, C. F. (1990). Estimating Net Realizable Value for Distressed Real Estate. Journal of Real Estate Research, 5(1), 129-139.

Susilawati, C., \& Lin, V. C. C. (2006). Case analysis of auction market in Brisbane housing system. Pacific Rim Real Estate Conference, Auckland.

T.S.E.I. Association. (2017). Studio dei tempi dei tribunali italiani in materia di procedure esecutive individuali.

Wong, W. C., Ng, P. L., Lee, J. Y. M., \& Daud, M. N. (2015). Apartment foreclosure discount in Kuala Lumpur. Pacific Rim Property Research Journal, 21(2), 127-138. https:/ / doi.org/10.1080/14445921.2015.1058034

Wong, W. C., Lee, J. Y. M., Daud, M. D. N., \& Ng, P. L. (2017). Seller ethnicity and property characteristics: Foreclosure sales in Malaysia. International Journal of Housing Markets and Analysis, 10(4), 539-551. https:/ / doi.org/10.1108/IJHMA-01-2017-0002

www.immobiliare.it/aste-immobiliari/ available at 10.02.2020. 